\title{
ХАРАКТЕРИСТИКА КОНТИНГЕНТУ ХВОРИХ НА РАК МОЛОЧНОЇ ЗАЛОЗИ ХЕРСОНСЬКОЇ ОБЛАСТІ, ЯКІ ЗНАХОДЯТЬСЯ НА ОБЛІКУ П'ЯТЬ І БІЛЬШЕ РОКІВ
}

\author{
Комунальний заклад Херсонської обласної ради «Херсонський обласний онкологічний диспансер», \\ Україна
}

\begin{abstract}
Мета: вивчити структуру хворих на рак молочної залози (РМЗ) з терміном виживання понад п'ять років.
Матеріали і методи. Проведений аналіз хворих Херсонської області на РМЗ, які перебувають на обліку п'ять і більше років.

Результати. Хворі на РМЗ, які живуть п'ять і більше років, мають переважно (92,7\%) I та II стадію захворювання на момент встановлення діагнозу. За морфологічною будовою в структурі хворих на РМЗ переважають (89,5\%) залозисті раки. 76,1\% хворих на РМЗ, які живуть п'ять і більше років, отримали комбіноване та комплексне лікування. Аналіз повікової структури захворюваності на РМЗ показав наявність двох піків захворюванності: у віці 45-49 років (18,5\%) та 55-69 років (32,3\%).

Висновки. Висока виживаність хворих з І-ІІ стадіями захворювання підкреслює важливість ранньої діагностики раку. 3 метою виявлення РМЗ на ранніх стадіях жінкам віком 45-69 років необхідне проведення щорічного мамографічного скринінгу. Більшу виживаність хворих на РМЗ забезпечує комплексне і комбіноване лікування.
\end{abstract}

КЛЮчОВІ СЛОВА: рак молочної залози, виживаність.

У Херсонській області, як і в Україні, рак молочної залози (РМЗ) посідає перше місце у структурі онкологічної захворюваності та смертності жіночого населення. На перебіг захворювання та чутливість пухлини до терапії впливає багато чинників. Першими прогностичними факторами були клінічні характеристики пацієнток (вік, менструальний статус, розмір пухлини тощо). Згодом до них долучили морфологічні властивості пухлин (ступінь диференціювання, гістологічна форма тощо) [5] і молекулярний підтип (люмінальний, базальний, Her2/neu-позитивний, тричі негативний та гібридний підтипи). Суттєвий вплив на прогноз перебігу захворювання мають своєчасна діагностика [4-5], обсяги проведеного реабілітаційного лікування [1-3], проведення індивідуалізованого специфічного лікування відповідно до молекулярного виду пухлини.

Мета: вивчити структуру хворих на рак молочної залози з терміном виживання понад п'ять років.

Матеріали і методи. Проведений аналіз контингенту хворих Херсонської області на РМЗ, які перебувають на обліку п'ять і більше років. За даними Херсонського обласного канцер-реєстру, станом на 01.07.2014 року на диспансерному обліку знаходиться 26934 хворих на злоякісні новоутворення (2514,5 на 100 тис. населення), у тому числі 4141 хворий на РМЗ.

Результати дослідження та їх обговорення. 3 усієї кількості диспансерних хворих живуть п'ять і більше років 16487 осіб, що становить $61,2 \%$ від загальної кількості контингенту хворих, у тому числі $2709(16,4 \%)$ хворих на РМЗ, які у структурі хворих займають друге місце після немеланомних захворювань шкіри.

За місцем проживання хворі на РМЗ розподіляються наступним чином: мешканці міста 73,2\% (n=1983); сільські мешканці - 26,8\% $(\mathrm{n}=726)$. Співвідношення хворих на РМЗ міського населення до сільського становить 2,7:1.

Поширеність контингенту хворих, які перебувають на обліку понад п'ять років, становить 471,5 на 100 тис. жіночого населення, у тому числі 556,1 серед міських мешканців та 332,6 на 100 тис. сільських.

Аналіз вікової структури хворих на РМЗ, що перебувають на обліку п'ять і більше років, показав, що найбільша захворюваність реєструється у віці 55-69 років $(32,3 \%)$, на II місці $(18,5 \%)$ вік 45-49 років, на III місці $(14,3 \%)$ вік $50-54$ років.

Як видно з рис. 1, спостерігаються два пікові значення зростання захворюваності серед жіночого населення: у віці 45-49 та у віці 55-69 років. Найнижчий показник онкологічної захворюваності $(4,6 \%)$ спостерігаються у віковій категорії до 35 років.

Таким чином, живуть п'ять і більше років з РМЗ 1542 (56,9\%) особи працездатного віку (до 55 років), а вікова група, яка найбільш схильна до захворювання на РМЗ, - це 55-69 років.

(C) I.B. Сокур, 2014 


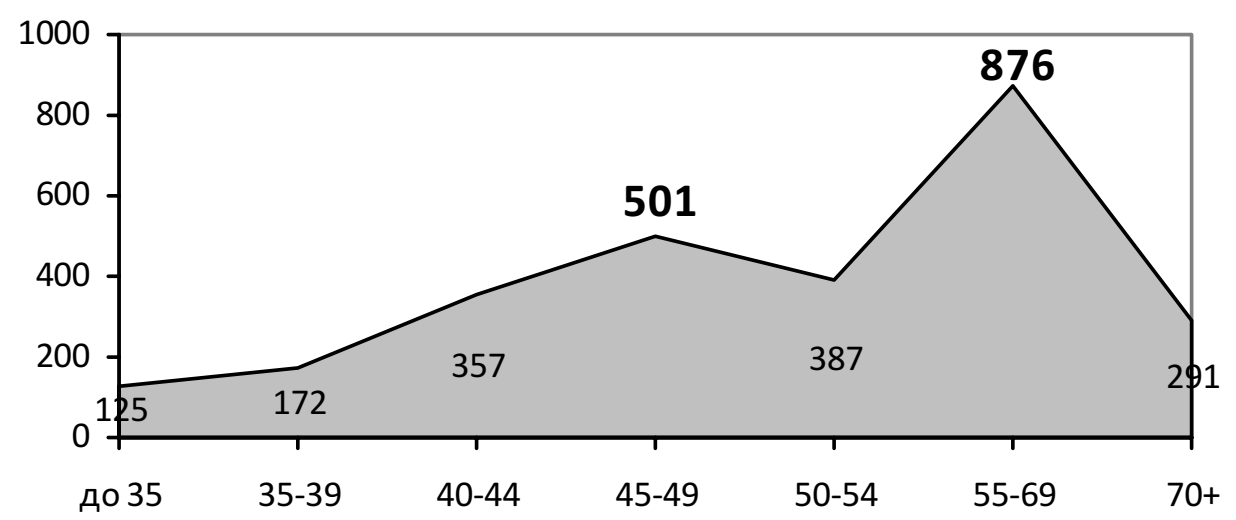

Рис.1. Вікова структура хворих Херсонської області на РМЗ, які стоять на диспансерному обліку п'ять і більше років, на момент встановлення діагнозу (абс. дані)

У структурі хворих, які знаходяться на обліку 5 років і більше, пацієнти з І-ІІ стадіями захворювання на момент взяття на облік становлять
92,7\%, що підтверджує важливість ранньої діагностики раку. Хворі з III-IV стадіями захворювання мають меншу загальну виживаність (рис. 2).

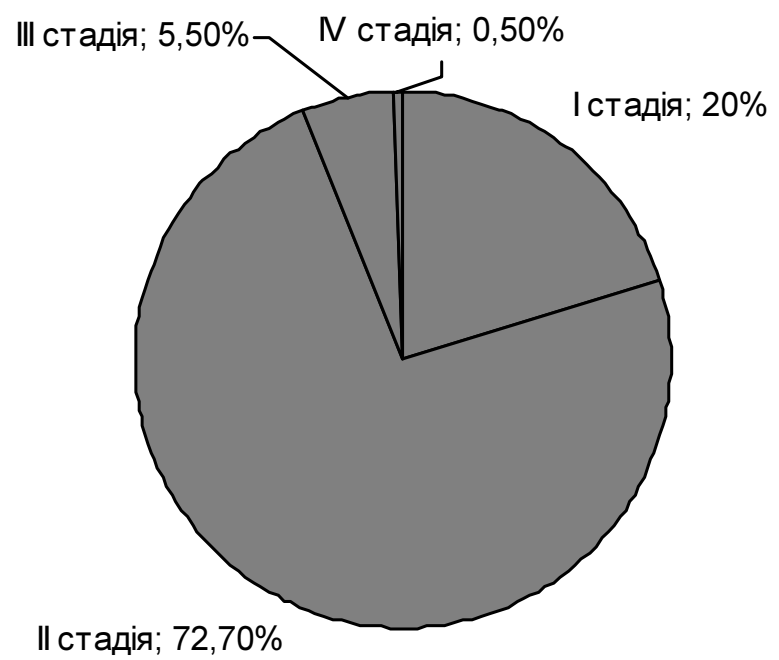

Рис.2. Структура хворих на РМЗ Херсонської області, які прожили п'ять і більше років, у розрізі стадій захворювання (\%)

Морфологічна верифікація діагнозу РМЗ підтверджена у 99,3\% хворих (n=2689), і тільки у $0,7 \%(n=20)$ діагноз встановлений лише клінічно або на підставі рентгенологічного (мамографічного) обстеження.

При аналізі структури хворих на РМЗ залежно від гістологічної форми встановлено, що залозисті раки (аденокарциноми) різної структури та ступеня диференціювання складають 89,5\% випадків ( $n=2426)$; хвороба Педжета та іншої гістологічної структури - 3,7\% та 5,9\% відповідно, саркома - 0,53\%, плоскоклітинні раки - у 0,37\% (рис. 3).

Структуру хворих на РМЗ у Херсонській області за молекулярним підтипом в останні три роки наведено у таблиці.

Таблиця. Розподіл хворих на РМЗ Херсонської області за молекулярним підтипом у 2011-2013 pp.

\begin{tabular}{|l|l|c|}
\hline \multicolumn{1}{|c|}{ Молекулярний підтип } & \multicolumn{1}{|c|}{ Характеристика } & $\begin{array}{c}\text { Середня кількість пацієнтів на рік, } \\
\text { n (\%) }\end{array}$ \\
\hline Люмінальний А & ER+, PR+, Her2/neu- & $145(42,9 \%)$ \\
\hline Люмінальний В & ER+, PR+, Her2/neu2+3+ & $83(23,7 \%)$ \\
\hline Гіперекспресія Her2/neu & ER-, PR-, Her2/neu2+3+ & $54(15,4 \%)$ \\
\hline Тричі негативний & ER-, PR-, Her2/neu- & $60(18,0 \%)$ \\
\hline
\end{tabular}




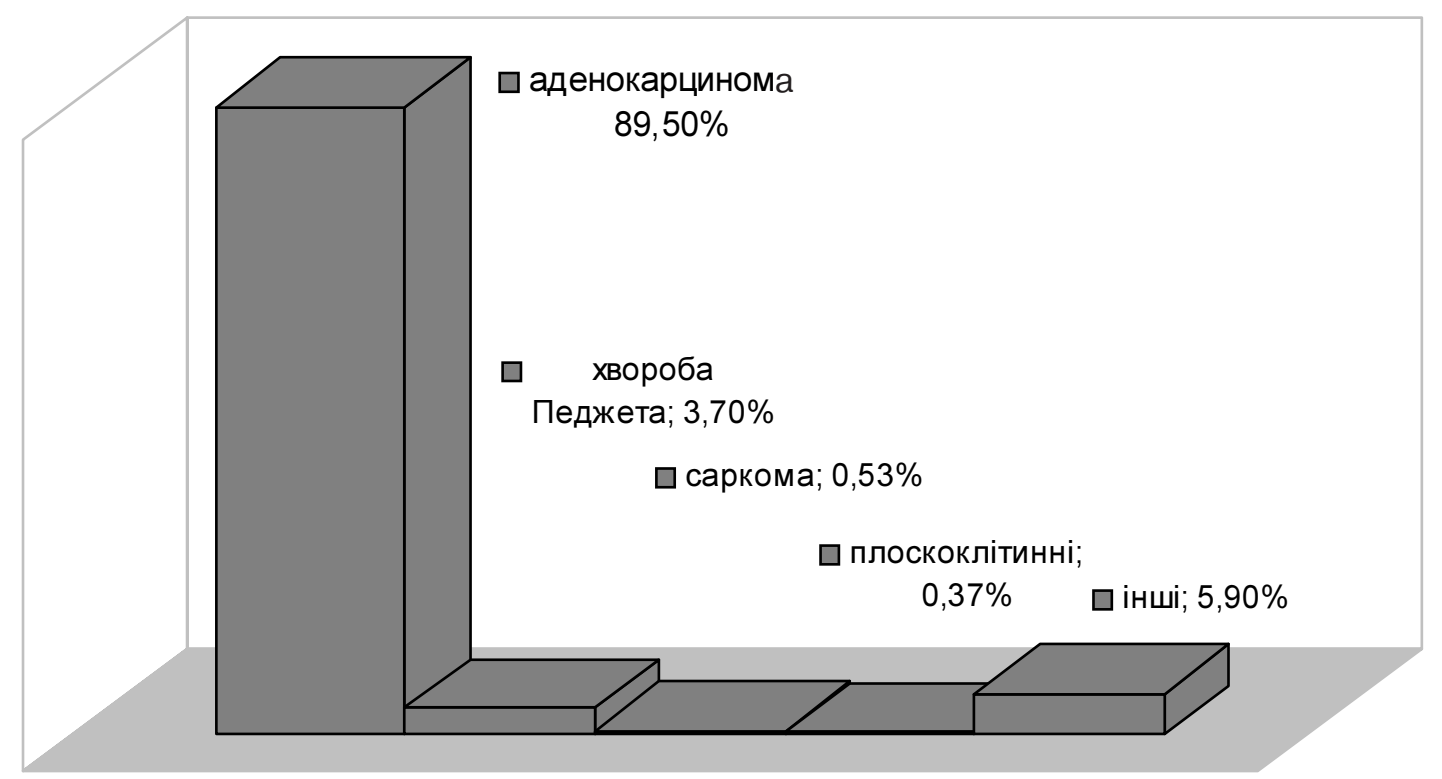

Рис.3. Структура хворих на РМз Херсонської області, які прожили п'ять і більше років, залежно від гістологічної форми (\%)

На виживаність хворих на РМЗ, крім віку, стадії захворювання, гістологічної форми та молекулярного підтипу, суттєвий вплив має проведення спеціального лікування. При аналізі контингенту хворих на РМЗ, що знаходяться на обліку п'ять і більше років, встановлено, що 76,1\% пацієнтів отримали комплексне $(40,1 \%, n=1087)$ та комбіноване $(36,0 \%, n=975)$ лікування. Монотерапію (це переважно хірургічне лікування $(n=583)$, хіміотерапію (n=14), гормональну ( $n=6)$ або променеву $(n=5)$ терапію) отримали 22,5\% (n=608) і лише 1,4\% $(n=39)$ пацієнтів, які відмовилися від лікування.

Відмовились від лікування в основному пацієнти віком 61-87 років ( $\mathrm{n=30}$ ), які мали I-ІІ стадію захворювання $(\mathrm{n}=36)$, у яких діагноз було встановлено цитологічно $(n=23)$, клінічно $(n=5)$, рентгенологічно $(n=11)$, натепер у більшості 3 них захворювання прогресує.

\section{Висновки}

1. Хворі на РМЗ, які живуть п'ять і більше років, мали в 92,7\% випадків I та II стадію захворювання на момент встановлення діагнозу, що ще раз підкреслює важливість ранньої діагностики раку.

2. За морфологічною будовою в структурі хворих на РМЗ переважають (89,5\% випадків) залозисті раки (аденокарциноми) різного ступеня диференціювання люмінальних підтипів А (42,9\%) i B $(23,7 \%)$.

3. Переважна більшість хворих на РМЗ, які живуть п'ять років і більше $(76,1 \%)$, отримали комбіноване та комплексне лікування.

4. Аналіз повікової структури захворюваності на РМЗ показав наявність двох піків захворюваності: у віці 45-49 років (18,5\%) та 55-69 років (32,3\%).

Зважаючи на найвищі рівні захворюваності жіночого населення Херсонської області у віці 4569 років, з метою виявлення РМЗ на ранніх стадіях необхідно планувати проведення щорічного мамографічного скринінгу, передусім для цієї категорії жінок, та оптимально використовувати обмежений ресурс наявного мамографічного обладнання.

Проведення комплексного і комбінованого лікування забезпечує більший відсоток хворих на РМЗ, які живуть п'ять і більше років. При цьому особливої актуальності набуває проблема організації реабілітаційно-відновлювального лікування пацієнток на стаціонарному, а потім на амбулаторному етапі з метою зменшення наслідків посттравматичних дисфункцій, лімфостазу верхніх кінцівок, підвищення якості життя хворих.

Перспективи подальших досліджень пов'язані з вивченням якості життя хворих на рак молочної залози.

\section{Список літератури}

1. Андрианов О. Клиническая реабилитация инвалидов с постмастэктомическим синдромом / О. Андрианов, Б. Поляков, С. Шахсуварян // Врач. - 2007. - № 5. - С. 71-73.

2. Драчева Л. В. Реабилитация после мастэктомии / Л. В. Драчева // Мед. сестра. - 2011. - № 2. - С. 6-10.

3. Комкова Е. П. Групповая психотерапія в физической реабилитации больных раком молочной железы / Е. П. Комкова, Н. П. Кокорина, Ю. А. Магарилл // Паллиативная медицина и реабилитация. - 2004. - № 2. - С. 56. 
4. Рак в Україні 2011-2012. Захворюваність, смертність, показники діяльності онкологічної служби / Федоренко З. П., Гулак Л. О., Михайлович Ю. Й. та ін.] // Бюл. Національного канцер-реєстру. - 2013. - № 14 (8). - С. $46-47$.

5. Шапочка Д. О. Особливості експресії NF-кB та ODC у пухлинах хворих на рак молочної залози з різним молекулярним профілем / Д. О. Шапочка, С. П. Залєток, М. І. Гнидюк // Онкологія. - 2014. - Т. 16, № 1 (59). - С. $33-39$.

\section{ХАРАКТЕРИСТИКА КОНТИНГЕНТА БОЛЬНЫХ РАКОМ МОЛОЧНОЙ ЖЕЛЕЗЫ ХЕРСОНСКОЙ ОБЛАСТИ, НАХОДЯЩИХСЯ НА УЧЕТЕ П'ЯТЬ И БОЛЬШЕ ЛЕТ}

И.В. Сокур

Комунальное учреждение Херсонского областного совета «Херсонский областной онкологический диспансер», Украина

Цель: изучить структуру больных раком молочной железы (РМЖ) со сроком выживания более пяти лет.

Материалы и методы. Проведен анализ больных Херсонской области РМЖ, которые находятся на учете п'ять и более лет.

Результаты. Больные РМЖ, которые живут п'ять и более лет, имеют преимущественно (92,7\%) I и II стадию заболевания на момент постановки диагноза. По морфологическому строению в структуре больных РМЖ преобладают (89,5\%) железистые раки. 76,1\% больных РМЖ, которые живут 5 лет и более, получили комбинированное и комплексное лечение. Анализ возрастной структуры заболеваемости РМж показал наличие двух пиков заболеваемости: в возрасте 45-49 лет (18,5\%) и 55-69 лет (32,3\%).

Выводы. Высокая выживаемость больных с I-II стадиями заболевания подчеркивает важность ранней диагностики рака. С целью выявления РМЖ на ранних стадиях женщинам в возрасте 45-69 лет необходимо проведение ежегодного маммографического скрининга. Большую выживаемость больных РМЖ обеспечивает комплексное и комбинированное лечение.

КЛЮЧЕВЫЕ СЛОВА: рак молочной железы, выживаемость.

\section{CHARACTERISTIC OF PATIENTS WITH BREAST CANCER IN KHERSON REGION, STAY ON THE ACCOUNT FIVE YEARS AND MORE}

I.V. Sokur

CE of the Kherson Regional Council "Kherson Regional Oncological Clinic", Ukraine

Purpose: to study structure of patients with breast cancer $(B C)$ with term survival more than five years.

Materials and methods. The analysis of patients of Kherson region with breast cancer, which stay on the account five years and more is carried out.

Results. Patients with breast cancer living five years and more have mostly $(92,7 \%)$ I and II stages of disease at the moment of establishment of diagnosis. The morphological structure in the structure of BC patients prevail $(89,5 \%)$ glandular cancers. $76,1 \%$ of patients with breast cancer who live five years and more, have received combined and complex treatment. Analysis of structure of the old-age incidence of breast cancer has shown presence of two peaks of morbidity: in age of 45-49 years (18,5\%) and 55-69 years (32,3\%).

Conclusions. High survival of patients with stage I-II of disease emphasizes importance of early diagnostics of cancer. In order to revealing breast cancer at early stages of women aged 45-69 years is necessary carrying out annual mammographic screening. Most survival of BC patients is provided comprehensive and combined treatment.

KEY WORDS: breast cancer, survival.

Відомості про автора:

Рукопис надійшов до редакції: 11.11.2014 р.

Сокур Ірина Володимирівна - головний лікар комунального закладу Херсонської обласної ради «Херсонський обласний онкологічний диспансер»; тел. служб.: +38(0552)359288. 